\title{
ACETAMINOPHEN PHARMACOKINETIC AND TOXICOLOGICAL ASPECTS: A REVIEW
}

\section{REVIEW ARTICLE}

FRANCO, Fernando Wendel ${ }^{1}$, MALONN, Maíra Casali ${ }^{2}$

FRANCO, Fernando Wendel. MALONN, Maíra Casali. Acetaminophen pharmacokinetic and toxicological aspects: a review. Revista Científica Multidisciplinar Núcleo do Conhecimento. Year 06, Ed. 12, Vol. 09, pp. 18-27. December 2021. ISSN:2448-0959, Access link in: https://www.nucleodoconhecimento.com.br/health/acetaminophen-pharmacokinetic, DOI: 10.32749/nucleodoconhecimento.com.br/health/acetaminophenpharmacokinetic

\section{ABSTRACT}

Paracetamol (Tylenol $\AA$ ) is a widely used non-steroidal anti-inflammatory drug responsible for many cases of intoxication and liver failure. When taken orally, it is absorbed and begins to be digested in the stomach. Paracetamol is primarily metabolized by the liver via phase I and phase II enzymes (glucuronyltransferases and sulfotransferases). When present in excess in the body, it forms an active metabolite known as $\mathrm{N}$-acetyl-para-benzoquinone-imine (NAPQI). This metabolite is a reactive species capable of binding to living cells and proteins causing injuries and adducts, which are largely responsible for damage, especially the liver. The study of paracetamol pharmacokinetics is important to understand its toxicity pathways and thus develop new therapies to prevent or minimize the damage caused by this drug. This review sought some of the most relevant works that address the pharmacokinetics of paracetamol to facilitate a general understanding of what has

\footnotetext{
${ }^{1}$ Doctor in Pharmacology. Master in Toxicological Biochemistry. Postgraduate in Clinical Analysis. Graduated in Pharmacy. ORCID: 0000-0002-4762-5855.

${ }^{2}$ Master in Analytical Chemistry. Graduation in Chemistry Degree. ORCID: 0000-0002-2600-5964.
}

RC: 103823

Available in: https://www.nucleodoconhecimento.com.br/health/acetaminophenpharmacokinetic 
been discovered so far on the subject. This study also aims to make patients aware of the possible harm that can occur when this drug is indiscriminately used.

Keywords: paracetamol, NAPQI, hepatotoxicity, pharmacokinetic.

\section{INTRODUCTION}

Acetaminophen (Tylenol®), often known as APAP, is a widely used analgesic and antipyretic. Adults and children use more than 300 million vials or packages of APAP or APAP-containing drugs in various formulations as over-the-counter or prescription drugs in the United States each year. The highest suggested dose for adults and adolescents (13 years) is $1,000 \mathrm{mg}$ after a single administration and 4,000 mg daily. According to the US Food and Drug Administration, to account for variations in metabolism between adults and children, dosage reduction is recommended in children (2-12 years) based on patient age or body weight (JI et al., 2012; JIANG et al., 2013).

Despite not having the same anti-inflammatory action as other drugs in the class, APAP is classified as a non-steroidal anti-inflammatory (NSAID). It is described as a drug associated with dangerous ingestion during suicide attempts or when not safely administered. It also does not have the same adverse gastrointestinal effects as other NSAIDs. However, overdoses of paracetamol (APAP) are a major cause of acute liver failure and damage in the Western world (LARSON et al., 2005).

Hepatic APAP metabolism is recognized as having a key role in the development of hepatotoxicity. APAP is extensively metabolized by conjugation events upon exposure to low doses, followed by subsequent oxidation processes to a lesser extent. However, when large doses of APAP are administered, the conjugation pathways become saturated and a greater proportion of the drug undergoes oxidative metabolism forming a highly reactive compound called $\mathrm{N}$-acetyl-pbenzoquinone imine (NAPQI) (WALUBO et al., 2004).

RC: 103823

Available in: https://www.nucleodoconhecimento.com.br/health/acetaminophenpharmacokinetic 
This hepatotoxic APAP metabolite is primarily generated by cytochrome P450 (CYP450) enzymes, a superfamily of hemoproteins that catalyze the oxidative metabolism of a wide range of foreign and endogenous substances. The CYP2E1, CYP1A2, and CYP3A4 enzymes are largely responsible for the bioactivation of APAP in the human liver, thus causing hepatotoxicity (MANYIKE et al., 2000).

NAPQI is produced by oxidation, which occurs through cytochrome P450 enzymes located in the centrilobular regions of the liver. This metabolite, with depletion of hepatic glutathione, is recognized as a critical early step in the development of hepatotoxicity (DONG et al., 2020). It also binds to cysteine groups on proteins to produce APAP protein adducts, which, causing an increase in alanine aminotransferase (ALT) and aspartate aminotransferase (AST) levels, are released from centrilobular hepatocytes and reach the peripheral blood after lysis of hepatocytes (JARSIAH et al., 2017).

\section{APAPS' ACTION MECHANISM}

\subsection{PHARMACOKINETIC}

APAP is used pharmacologically because of its analgesic, antipyretic and antiinflammatory properties. Medicine comes in a variety of forms and concentrations. The oral presentation can take the form of tablets, capsules, or liquids. Drug concentration varies by forms, such as 100 or $200 \mathrm{mg} / \mathrm{ml}$ solutions, 500 or $750 \mathrm{mg}$ tablets or capsules, and the presence or absence of other related formulations (SHAYIQ et al. 1999).

As long-term use of doses of up to $2 \mathrm{~g}$ per day is not related to liver damage, it is a viable alternative to the use of aspirin as an analgesic or antipyretic (SCHENKER et al., 2001). It is very beneficial for people who cannot use aspirin due to the low gastrointestinal irritation effect that occurs with other non-steroidal anti-inflammatory drugs (BRUNE et al., 2009). 
The cyclooxygenase 2 enzyme is known to be inhibited by APAP (COX-2). In the presence of abundant peroxides, this action is avoided. As the levels of peroxide in the central nervous system are low, the analgesic and antipyretic effects of APAP on the central nervous system are warranted. As a result, the excess of peroxides in other inflammatory areas explains its limited anti-inflammatory action. (KIS et al., 2005).

The COX-3 isoform, originally derived from the original enzyme cyclooxygenase (COX), is related to the presence of APAP in the central nervous system. This was considered a variation of COX-1 and COX-2. Afterward, a new gene responsible for the expression of this COX isoform was identified in the canine brain. (KIS et al. 2005).

The ability of APAP to quench the tyrosyl radical contained in the molecular structure of Prostaglandin-Endoperoxide Synthase (PGE) was postulated to explain the mechanism of action of inhibition of the COX enzyme via prostaglandins. PGEs have also been described to be inhibited by substances that are similar to APAP but are monomethylated. In vivo and in vitro studies using similar compounds with fluorine atoms close to the hydroxyl group, adjacent to the amide group, or even adjacent to the acetamide group have also been able to inhibit COX (SMITH et al., 2009; ARONOFF et al., 2006).

\subsection{ABSORPTION}

The time it takes for acetaminophen to be absorbed after being taken orally is determined by the time it takes for the stomach to empty. Most nutrients and other exogenous chemicals such as APAP come into contact with the liver. It is then quickly and completely absorbed by the small intestine, where these chemicals are absorbed and subsequently transported to various tissues. The first-pass effect, commonly known as metabolism, is a feature of oral absorption. In therapeutic doses, the peak plasma concentration is obtained in 60 to 120 minutes, with a halflife of 1.5 to 2.5 hours and 4-8 hours in liver lesions. These numbers are considered

Available in: https://www.nucleodoconhecimento.com.br/health/acetaminophenpharmacokinetic 
once therapeutic dosages have been consumed. In overdoses, these levels are extended, with a direct link to the dosage consumed (CHEN et al., 1985; MAZALEUSKAYA et al., 2015).

\subsection{BIOTRANSFORMATION AND DISTRIBUTION}

Biotransformation enzymes are present in abundance throughout the body, although they are concentrated in the liver. When the liver is removed and homogenized, followed by consecutive centrifugations at increasing speeds, various liver cell fractions are obtained. The biotransformation reactions of xenobiotics, which are generally categorized as microsomal or cytosolic, take place in these cells. Most Phase I reactions are catalyzed by microsomal enzymes, whereas Phase II biotransformations are largely catalyzed by cytosolic enzymes (KOSTRUBSKY et al., 2007).

Most acetaminophen consumed is immediately conjugated in a phase II detoxification process, followed by sulfation and glucuronidation before being eliminated. In conjugation processes, the enzyme uridine glucuronic transferase (UGT) recognizes certain functional groups and uses a common substrate, uridine 5diphosphate-glucuronic acid (UDP-glucuronic). There are two families (UGT1 and UGT2) and three subfamilies (UGT1A, UGT2A and UGT2B) (ZHAO et al., 2011).

Paracetamol metabolism is mediated by UGT isoforms 2B15, 1A1, 1A6, and $1 \mathrm{~A} 9$. They carry out the glucuronidation process, which transfers glucuronic acid from UDP-glucuronic acid to APAP. With the help of glucuronic acid, an APAP conjugate is produced and then excreted (MUTLIB et al. 2006).

The superfamily of sulfotransferases (SULT) catalyzes the conjugation of sulfate with endogenous and foreign chemicals in the sulfation processes. SULT 1A1 is a (phenol) sulfotransferase that preferentially catalyzes the sulfation of tiny flat phenols and APAP. A complex is produced after sulfate conjugation, in which APAP is excreted (LINAKIS et al., 2018; YAMAMOTO et al., 2015).

RC: 103823

Available in: https://www.nucleodoconhecimento.com.br/health/acetaminophenpharmacokinetic 
But another set of monooxygenase enzymes in the hepatic microsomal p450 system oxidizes endogenous and foreign substances. This system converts the APAP that it metabolizes into $\mathrm{N}$-acetyl-p-benzoquinone-imine (NAPQI). This can bind to cellular proteins, causing them to be damaged. NAPQI is neutralized by Glutathione Stransferase (GST) through conjugation with the tripeptide glutathione to preserve cell structure (GONZALEZ, 2005).

The generation of reactive metabolites that bind to microsomal proteins is attributed to cytochrome p450 enzymes, according to studies using human liver microsomes. CYP1A1, 1A2, 2E1, 3A1, and 3A2 isoforms may be involved in metabolic activation. About $70 \%$ of covalent bonds are formed from cysteine residues found in liver proteins (KIM et al., 2001).

In several studies, the CYP2E1 enzyme is the most effective in bioactivation NAPQI in dangerous APAP intakes. The proportional ratio of NAPQI to the production of 3hydroxy-paracetamol (3-OH PAR), an intermediate metabolite in APAP detoxification, was about 6 to 1 . The CYP2A6 isoform then revealed a 3 to 1 percentage of production of NAPQI (BESSEMS et al. 2001; KENNA et al. 2013).

After being biotransformed, to be distributed, APAP is transported by the blood bound to plasma proteins after intestinal absorption. When it passes through most tissues, it can attach to cells, causing damage to the liver and kidneys, which is most noticeable in acute poisoning. It is then evenly dispersed throughout the body's fluids. This allows APAP to cross the blood-brain barrier as well as the placental barrier, where it can harm fetal hepatocytes (SLOSKY et al. 2013).

\subsection{EXCRETION}

Most acetaminophen undergoes glucuronidation or sulfation when ingested at therapeutic levels, allowing it to be excreted conjugated with glucuronic acid or sulfate by renal or biliary excretion. Only a small part of the excess is metabolized by the p450 microsomal system, which generates NAPQI, which is rapidly conjugated to

Available in: https://www.nucleodoconhecimento.com.br/health/acetaminophenpharmacokinetic 
reduced glutathione and later excreted. On the first day after ingestion, the drug may be reabsorbed in the urine, especially if it has been conjugated to glucuronic acid, sulfuric acid, or cysteine (CHEN et al. 1998).

Excretion of mercapturic acid is also possible, although it is dose-dependent. In animal studies, it has been found to increase when multiple hepatotoxic doses are administered. The reactive metabolite NAPQI is formed after an overdose of APAP. When trying to neutralize the aforementioned metabolite, glutathione is depleted. NAPQI begins to damage liver cells when glutathione stores are low. The decrease in the rate of glutathione resynthesis is usually insufficient in intoxications, requiring its administration (KIS et al., 2005).

In humans, about 30 to 55 percent of administered APAP is excreted in the urine as PAR sulfate conjugate (PAR-Sulp) and PAR glucuronide conjugate (PAR-Gluc); 4 percent of the dosage is made up of PAR-cysteine conjugates (PAR-Cys) and PAR $\mathrm{N}$-acetyl-cysteine conjugates (PAR-NAC) (BESSEMS et al., 2001).

The kidneys and intestines are also involved in the metabolism of the APAP metabolite. Gamma Glutamyl Transpeptidase (GGT) and Dipeptidase are enzymes found in both organs. PAR conjugates are broken down by these enzymes. Glutathione-conjugated PAR (PAR-SG), cysteine-glycine-conjugated PAR (PAR-CG) and cysteine-conjugated PAR (PAR-CC) are some of them (PAR-Cis). The kidneys are also involved in the processing of sulfated PAR metabolites, either by glomerular filtration or biotransformation followed by excretion (FRANCO et al., 2015).

\section{CONCLUSION}

Although acetaminophen is a drug commonly used throughout the world, the public is not familiar with the knowledge of its pharmacokinetics. Due to its widespread use, the danger of dangerous ingestion is quite high. This review sought to explain in detail the pharmacokinetic mechanisms of acetaminophen through some of the most relevant scientific articles ever published. The purpose of this review is also to alert

RC: 103823

Available in: https://www.nucleodoconhecimento.com.br/health/acetaminophenpharmacokinetic 
the consuming public about the harm that can be caused when acetaminophen is used indiscriminately.

\section{REFERENCES}

ARONOFF, DAVID M.; OATES, JOHN A.; BOUTAUD, OLIVIER. New insights into the mechanism of action of acetaminophen: its clinical pharmacologic characteristics reflect its inhibition of the two prostaglandin $\mathrm{H} 2$ synthases. 2006. Disponível em: https://deepblue.lib.umich.edu/bitstream/handle/2027.42/109994/cptclpt20062.pdf?se quence=1. Acesso em: 30/09/2020

BESSEMS, J.G., VERMEULEN, N.P., 2001. Paracetamol (acetaminophen)-induced toxicity: molecular and biochemical mechanisms, analogues and protective approaches. Critical reviews in toxicology, 31(1), pp.55-138. Disponível em: https://pubmed.ncbi.nlm.nih.gov/11215692/ Acesso em: 20/09/2020

BRUNE, KAY; HINZ, BURKHARD; OTTERNESS, IVAN. Aspirin and acetaminophen: should they be available over the counter?. Current rheumatology reports, v. 11, n. 1, p. 36-40, 2009. Disponível em: https://pubmed.ncbi.nlm.nih.gov/19171110/ Acesso em: $31 / 09 / 2020$

CHEN, W., KOENIGS, L. L., ThOMPSON, S. J., PETER, R. M., RETTIE, A. E., TRAGER, W. F., NELSON, S. D. (1998). Oxidation of acetaminophen to its toxic quinone imine and nontoxic catechol metabolites by baculovirus-expressed and purified human cytochromes P450 2E1 and 2A6. Chemical research in toxicology, 11(4), 295-301. Disponível em: https://pubmed.ncbi.nlm.nih.gov/9548799/ Acesso em: $30 / 09 / 2020$

DONG, H., HAINING, R. L., THUMMEL, K. E., RETTIE, A. E., NELSON, S. D. (2000). Involvement of human cytochrome P450 2D6 in the bioactivation of acetaminophen. Drug metabolism and disposition, 28(12), 1397-1400. Disponível em: https://pubmed.ncbi.nlm.nih.gov/11095574/ Acesso em: 30/08/2020 
FRANCO, F. W. (2015). Artemísia absinthium minimiza a toxicidade induzida por paracetamol em camundongos. Disponível em: https://repositorio.ufsm.br/handle/1/17286 Acesso em: 31/08/2020

GONZALEZ, F.J., 2005. Role of cytochromes P450 in chemical toxicity and oxidative stress: Studies with CYP2E1. Mutation Research - Fundamental and Molecular Mechanisms of Mutagenesis, 569(1-2), pp.101-110. Disponível em: https://pubmed.ncbi.nlm.nih.gov/15603755/ Acesso em: 13/09/2020

JARSiAH, P., NOSRATI, A., ALIZADEH, A., HASHEMI-SOTEH, S. M. B. (2017). Hepatotoxicity and ALT/AST enzymes activities change in therapeutic and toxic doses consumption of acetaminophen in rats. International Biological and Biomedical Journal, 3(3), 119-124. Disponível em: http://ibbj.org/browse.php?a_id=129\&sid= Acesso em: 03/09/2020

JI, P., WANG, Y., LI, Z., DODDAPANENI, S., HERTZ, S., FURNESS, S., SAHAJWALLA, C. G. (2012). Regulatory review of acetaminophen clinical pharmacology in young pediatric patients. Journal of pharmaceutical sciences, 101(12), 4383-4389. Disponível em: https://pubmed.ncbi.nlm.nih.gov/23073837/ Acesso em: 30/11/2020

JIANG, X. L., ZHAO, P., BARRETT, J. S., LESKO, L. J., SCHMIDT, S. (2013). Application of physiologically based pharmacokinetic modeling to predict acetaminophen metabolism and pharmacokinetics in children. CPT: pharmacometrics \& systems pharmacology, 2(10), 1-9. Disponível em: https://www.ncbi.nlm.nih.gov/pmc/articles/PMC3817375/ Acesso em: 12/09/2020

KENNA, J. GERRY. A new twist to an old tale: novel insights into the differential toxicities of acetaminophen and its regioisomer $\mathrm{N}$-acetyl-meta-aminophenol (AMAP). Archives of toxicology, v. 87, n. 1, p. 15-18, 2013. Disponível em: https://link.springer.com/article/10.1007/s00204-012-0945-9 Acesso em: 30/09/2020 
KIM, H., PUTT, D. A., ZANGAR, R. C., WOLF, C. R., GUENGERICH, F. P., EDWARDS, R. J., NOVAK, R. F. (2001). Differential induction of rat hepatic cytochromes $\mathrm{P} 4503 \mathrm{~A} 1,3 \mathrm{~A} 2,2 \mathrm{~B} 1,2 \mathrm{~B} 2$, and $2 \mathrm{E} 1$ in response to pyridine treatment. Drug metabolism and disposition, 29(3), 353-360. Disponível em: https://citeseerx.ist.psu.edu/viewdoc/download?doi=10.1.1.902.1553\&rep=rep1\&type $=$ pdf Acesso em: 30/12/2020

KIS, B., SNIPES, J. BUSIJA, D.W., 2005. Acetaminophen and the cyclooxygenase-3 puzzle: sorting out facts, fictions, and uncertainties. The Journal of pharmacology and experimental therapeutics, 315(1), pp.1-7. Disponível em: https://pubmed.ncbi.nlm.nih.gov/15879007/ Acesso em: 29/09/2020

KOSTRUBSKY, S. E., STROM, S. C., ELLIS, E., NELSON, S. D., MUTLIB, A. E. (2007). Transport, metabolism, and hepatotoxicity of flutamide, drug-drug interaction with acetaminophen involving phase I and phase II metabolites. Chemical research in toxicology, 20(10), 1503-1512. Disponível em: https://pubmed.ncbi.nlm.nih.gov/17900172/ Acesso em: 28/09/2020

LARSON AM, POLSON J, FONTANA RJ, DAVERN TJ, LALANI E, HYNAN LS. Acetaminophen-induced acute liver failure: results of a United States multicenter, prospective study. Hepatology 2005; 42: 1364-1372. PMID: 16317692 Disponível em: https://pubmed.ncbi.nlm.nih.gov/16317692/ Acesso em: 27/09/2020

LINAKIS, M. W., COOK, S. F., KUMAR, S. S., LIU, X., WILKINS, D. G., GAEDIGK, R., VAN DEN ANKER, J. N. (2018). Polymorphic expression of UGT1A9 is associated with variable acetaminophen glucuronidation in neonates: a population pharmacokinetic and pharmacogenetic study. Clinical pharmacokinetics, 57(10), 1325-1336. Disponível em: https://pubmed.ncbi.nlm.nih.gov/29654492/ Acesso em: $25 / 09 / 2020$

MAZALEUSKAYA, L. L., SANGKUHL, K., THORN, C. F., FITZGERALD, G. A., ALTMAN, R. B., KLEIN, T. E. (2015). PharmGKB summary: pathways of acetaminophen metabolism at the therapeutic versus toxic doses. Pharmacogenetics RC: 103823

Available in: https://www.nucleodoconhecimento.com.br/health/acetaminophenpharmacokinetic 
and

genomics,

25(8),

416.

Disponível

em:

https://pubmed.ncbi.nlm.nih.gov/26049587/ Acesso em: 06/09/2020

MANYIKE, P. T., KHARASCH, E. D., KALHORN, T. F., SLATTERY, J. T. (2000). Contribution of CYP2E1 and CYP3A to acetaminophen reactive metabolite formation. Clinical Pharmacology \& Therapeutics, 67(3), 275-282. Disponível em: https://pubmed.ncbi.nlm.nih.gov/10741631/ Acesso em: 30/11/2020

MUTLIB, A. E., GOOSEN, T. C., BAUMAN, J. N., WILLIAMS, J. A., KULKARNI, S., KOSTRUBSKY, S. (2006). Kinetics of Acetaminophen Glucuronidation by UDPGlucuronosyltransferases 1A1, 1A6, 1A9 and 2B15. Potential Implications in Acetaminophen- Induced Hepatotoxicity. Chemical research in toxicology, 19(5), 701-709. Disponível em: https://pubs.acs.org/doi/abs/10.1021/tx050317i Acesso em: 23/09/2020

SCHENKER, S. S. K. V., SPEEG JR, K. V., PEREZ, A., FINCH, J. (2001). The effects of food restriction in man on hepatic metabolism of acetaminophen. Clinical Nutrition, 20(2), 145-150. Disponível em: https://pubmed.ncbi.nlm.nih.gov/11327742/ Acesso em: 20/09/2020

SHAYIQ, R. M., ROBERTS, D. W., ROTHSTEIN, K., SNAWDER, J. E., BENSON, W., MA, X., BLACK, M. (1999). Repeat exposure to incremental doses of acetaminophen provides protection against acetaminophen-induced lethality in mice: an explanation for high acetaminophen dosage in humans without hepatic injury. Hepatology, 29(2), 451-463. Disponível em: https://pubmed.ncbi.nlm.nih.gov/9918922/ Acesso em: 31/09/2020

SLOSKY, L. M., THOMPSON, B. J., SANCHEZ-COVARRUBIAS, L., ZHANG, Y., LARACUENTE, M. L., VANDERAH, T. W., DAVIS, T. P. (2013). Acetaminophen Modulates P-Glycoprotein Functional Expression at the Blood-Brain Barrier by a Constitutive Androstane Receptor-Dependent Mechanism. Molecular pharmacology, 
84(5), 774-786. Disponível em: https://pubmed.ncbi.nlm.nih.gov/24019224/ Acesso em: $30 / 09 / 2020$

SMITH, HOWARD S. Potential analgesic mechanisms of acetaminophen. Pain physician, v. 12, n. 1, p. 269-280, 2009. Disponível em: https://www.painphysicianjournal.com/current/pdf?article=MTE4NA\%3D\%3D\&journal $=47$ Acesso em: 30/05/2020

Walubo, A., BARR, S., ABraham, A. M., COETSEe, C. (2004). The role of cytochrome-P450 inhibitors in the prevention of hepatotoxicity after paracetamol overdose in rats. Human \& experimental toxicology, 23(1), 49-54. Disponível em: https://pubmed.ncbi.nlm.nih.gov/15027815/ Acesso em: 30/04/2020

YAMAMOTO, A., LIU, M. Y., KUROGI, K., SAKAKIBARA, Y., SAEKI, Y., SUIKO, M., LIU, M. C. (2015). Sulphation of acetaminophen by the human cytosolic sulfotransferases: a systematic analysis. The Journal of Biochemistry, 158(6), 497504. Disponível em: https://pubmed.ncbi.nlm.nih.gov/26067475/ Acesso em: $30 / 03 / 2020$

ZHAO, P., KALHORN, T.F., SLATTERY, J.T., 2002. Selective mitochondrial glutathione depletion by ethanol enhances acetaminophen toxicity in rat liver. Hepatology, 36, pp.326-335. Disponível em: https://pubmed.ncbi.nlm.nih.gov/12143040/ Acesso em: 30/09/2020

Posted: March, 2021

Approved: December, 2021. 